\title{
Constitutional Recognition: retiring from the hamster wheel
}

\author{
Grace Hartley \\ University of Technology Sydney, Faculty of Arts and Social Sciences, PO Box 123, \\ Ultimo NSW 2007, Australia. grace.k.hartley@student.uts.edu.au
}

The process of realising constitutional recognition for Australia's Indigenous population can be characterised as a cycle: the government commissions a group of experts to give recommendations, that group presents their recommendations, the government either rejects or fails to act on said recommendations and so, the government commissions a new group of experts and the cycle starts again. Each time the government will commission a similar group of experts, with a similar aim, bestowing upon the group a unique title in an attempt to mask the hamster-wheel that is the constitutional recognition debate.

The most recent proposal, The Uluru Statement from the Heart, is arguably the most suitable, conservative and accommodating recommendation put to the Australian government over the past decade. Despite the government rejecting this recommendation, the Uluru Statement from the Heart, justifiably, remains an aspiration for Australia's Indigenous population. The advantages of the Uluru Statement from the Heart can be understood through its three core features: symbolic recognition, the First Nations' Voice, and the Makarrata Commission (Referendum Council 2017).

Whilst branded by many as a tokenistic form of constitutional recognition, symbolic recognition remains important so long as it is accompanied by more substantive forms of recognition (Davis 2019). Symbolic recognition establishes a national sentiment and unified understanding that Indigenous sovereignty was never ceded. However, understanding symbolic recognition's limited substantive impact, the Referendum Council only call for symbolic recognition in a legislative, rather than constitutionally enshrined form (Referendum Council 2017). 
The First Nations Voice is a recommendation that is both compatible with the Australian legal system and empowering for Indigenous Australia. Twomey argues that the First Nation's Voice mirrors the structure of a number of parliamentary consultative bodies previously established; such as the Australian Law Reform Commission or the Australian Human Rights Commission (Twomey 2018). The constitutional enshrinement of this particular consultative body is crucial given the historical tendency of non-Indigenous governance abolishing rights of Aboriginal people in Australia (Twomey 2018). Furthermore, the First Nation's Voice will provide an accurate representation of Aboriginal needs and wants, subsequently enhancing active citizenship by Aboriginal people (Larkin \& Galloway 2018).

The Referendum council recommend that The Makarrata Commission be established, to supervise a truth-telling, negotiation process for constitutional recognition. Before prior wrongs can be somewhat remedied through constitutional recognition, it is crucial that there is a more complete understanding of the historical adversities faced by Aboriginal people and that there are no power imbalances remaining (Davis 2019). The Makarrata Commission aims to establish a balance in legal standing and understanding of one another's perspective to ensure an effective negotiation process.

The Uluru Statement from the Heart is the most suitable recommendation put to the Australian government in the past decade. It provides the government with a perfect opportunity to adjourn the discursive phase on constitutional recognition and enact meaningful change. 


\section{References}

Davis, M. 2019, The Uluru Statement from the Heart and its pedagogic implications, The University of Melbourne, Melbourne, viewed 6 June 2019, $<$ https://education.unimelb.edu.au/news-and-events/events/2019/dls/the-ulurustatement-from-the-heart-and-its-pedagogic-implications>.

Larkin, D. \& Galloway, K., 'Uluru Statement From the Heart: Australian Public Law Pluralism', Bond Law Review, vol. 30, no. 2, pp. 1-11.

Parliament of Australia 2019, List of Previous Recommendations, Parliament of Australia, viewed 1 June 2019, $<$ https://www.aph.gov.au/Parliamentary_Business/Committees/Joint/Constitutional_R ecognition_2018/ConstRecognition/Interim_Report/section?id=committees\%2Freport jnt\%2F024174\%2F26121>.

Referendum Council 2017, The Uluru Statement from the Heart, Referendum Council, viewed 1 June 2019,

$<$ https://www.referendumcouncil.org.au/sites/default/files/201705/Uluru_Statement_From_The_Heart_0.PDF>.

Twomey, A. 2019, 'Why an Indigenous Voice would not be 'third chamber' of parliament', The Sydney Morning Herald, 28 May, viewed 1 June 2019, $<$ https://www.smh.com.au/national/why-an-indigenous-voice-would-not-be-thirdchamber-of-parliament-20190526-p51r7t.html>. 